\title{
SOCIAL-PSYCHOLOGICAL ASPECTS OF INTRAGROUP ADJUSTMENT IN ADOLESCENTS PENITENTIARY SYSTEMS
}

\section{Bielavina T. I.}

\section{INTRODUCTION}

Changes in modern Ukraine cover the most diverse layers of social life, which is constituted by different traditions, norms of behavior, social institutions, and touches upon philosophical, scientific, moral, legal, political, aesthetic and other aspects of it. Most of the socio-economic, political changes affect the spheres of culture, family, education and upbringing, for which the fundamental values of human consciousness are inherent in the greatest extent. In the context of the ongoing transformations, they retain the greatest stability and remain the most important social institutions; they cannot but be influenced by large-scale changes in the economic, social, and cultural context.

The criminal subculture, being an existing objective reality, occupies a certain place in the system of human relations and values. Therefore, along with the priority tasks facing psychological science today, one of the key is the problem of the study of a special system of intragroup relationships and interpersonal communications in special educational institutions with varying degrees of prescribed behavior and mode.

In this connection, the problem of the vital activity of the individual and the group in the penitentiary systems, which, to a certain extent, are seen as a reduced model of a sociable congruence, deserves attention. It can be described as a problem related to group formation in conditions of forced relative localization and isolation of the group in relation to a certain contingent, a specific type of joint activity, to a certain age, gender, from the standpoint of not only general, age and pedagogical, but also social psychology.

On this basis, it is necessary to determine the socio-psychological aspects of intergroup and intgroup interaction in adolescent groups, its social-perceptual aspect; to study peculiarities of intragroup structure of real groups in conditions of penitentiary institution. 


\section{Social-psychological studies of personalities and groups of minors}

The social reality of modern times, the change of attitudes regarding spiritual and material values in the broad society, in certain social strata and specific groups caused both positive changes and new problems. They were caused by the collapse of previous mono-ideologized models of relations between society and the state, the destruction of myths, stereotypes, prejudices.

In both domestic and foreign practice, there is considerable theoretical and empirical experience in the development of the problem of group and intergroup interaction, mutual perception in the group and between groups, intragroup structuring. It is advisable to analyze how much the problem of the status of the teenager in the system of his social relations in special conditions is studied in the psychological literature.

Back in the late XIX - early XX centuries, attempts were made to study the extent and nature of the group's influence on the mental functions, behavior and activities of the individual. This was reflected in the scientific publications of G. Zimmel ${ }^{1}$ and C. Kuli ${ }^{2}$, which can be attributed to the beginning of the experimental stage in the study of groups (for example, the theory of primary groups, the theory of the "mirror self"). In the first third of the twentieth century, researches within this problem became widespread and were reflected in the works of V. Bekhterev (1921, 1923) ${ }^{3}$, V. Moede ${ }^{4}$, J. Moreno ${ }^{5}$, F. Allport ${ }^{6}$, G. Tarde ${ }^{7}$.

On the basis of the accumulated experimental material, at this stage the conclusion was made about the significant influence of direct contact of people in the group on the course of mental processes and the emergence of "extra-individual" phenomena (eg, facilitation, inhibition). It has been established that these and other "extra-individual" phenomena are characteristic of a certain set of individuals as a whole.

\footnotetext{
1 Зиммель Г. Социальная дифференциация: Социологические и психологические исследования / Г. Зиммель // Избран. в 2 т: 2Т: Созерцание жизни. - М: Юрист. - 1996. - 164 с.

${ }^{2}$ Кули Ч. Человеческая природа и социальный порядок : [Науч. изд.] : пер. с англ. / Ч. Кули М. : ИдеяПресс : Дом интеллектуальной книги, 2000. - 309 с.

${ }^{3}$ Бехтерев В.М. Основные задачи рефлексологии физического труда [Текст] / В.М. Бехтерев // Вопросы изучения и воспитания личности. 1919. № 1. С. 51.

${ }^{4}$ Moede W. Experimentelle Massenpsychologie. Beitrage zur Experimentalpsychologie der Gruppe. Leipzig: Hirzel, 1920. - 239.

5 Морено Я.Л. Социометрия: Экспериментальный метод и наука об обществе / Пер. с англ. А. Боковикова. - М. :: Академический проект, 2001. - 320 с.

6 Олпорт Г. Становление личности: Избранные труды / [Пер. с англ. Л. В. Трубицыной и Д. А. Леонтьева]; под общ. ред. Д.А. Леонтьева. М.: Смысл, 2002. - 462 с.

${ }^{7}$ Тард Г. Социальные законы Пер. с фр. Изд. 2-е. - М.: Книжный дом «ЛИБРОКОМ», 2009. - 64 с.
} 
Finding and fixing differences in human behavior in conditions of either isolation or publicity was the first step in the comparative study of individual and group effectiveness, in identifying a number of purely group phenomena and factors of subjective psychological order.

The achievement of this period of scholarly search has become a persistent recognition of the existence within formal groups of informal divisions that are formed on the basis of interpersonal emotional relationships. The formation of group norms and values, largely determine the behavior and activity of the individual. The study of these phenomena was carried out in two aspects of the life of the group: formally set functional and business relationships, as well as informal emotionalpersonal relationships that have a decisive influence on them.

The problem of social-psychological interaction of personality and society, its functionally-business and emotional-personal relationships in large and small groups is devoted to the scientific search of many domestic researchers of the second half of the twentieth and the beginning of the twentieth centuries. (G.Andreeva ${ }^{8}$, A. Asmolov ${ }^{9}$, S. Bagretsov ${ }^{10}$, P. Ghornostay ${ }^{11}$, A. Petrovsky ${ }^{12}$, etc.).

In accordance with the concept of personalization, developed at the end of the twentieth century, A. Petrovsky distinguished three processes of personality formation: adaptation as becoming socially typical; individualization, as the acquisition of individuality; integration as a change in the life of others. In this context, the distinctive feature of adolescence is the prevalence of individualization over adaptation, and the adolescent's personality develops in the developing group, the teenager defines himself through the group, through society. Teenagers are constantly included in the system of interpersonal relationships in different groups, interacting and communicating with each other ${ }^{13}$.

On the basis of the accumulated research material the conclusion was made about the significant influence of joint activity on the development of the human psyche. Moreover, the "internal" mental processes are

\footnotetext{
${ }^{8}$ Андреева Г.М. Социальная психология. М.: Аспект-Пресс. - 2000. С. 186-190, 274-288.

9 Асмолов А.Г. Психология личности: культурно-историческое понимание развитие человека (3-е изд. Испр и доп.). - М., Академия, Смысл, 2007. - 528 с.

${ }^{10}$ Багрецов С.А. и др. Диагностика социально - психологических характеристик малих груп. - СПб.: Питер,1999. - 638 с.

11 Психологія групової ідентичності: закономірності становлення: [монографія] / [П.П. Горностай, О.А. Ліщинська, Л.Г. Чорна та ін.] ; за наук. ред. П.П. Горностая. - К. : Міленіум, 2014. - 252 с.

${ }_{12}$ Петровский А.В. Психология развивающейся личности: монография. М.: Педагогика, 1987. - 240 с.

13 Петровский А.В. Психология развивающейся личности: монография. М.: Педагогика, 1987. - 240 с.
} 
transformed forms of "external" group activity of people, the result of their cooperation. In the course of adulthood, relationships with peers become more selective and stable, and the basis of preference and choice are the personal characteristics of the partner. Status position in the group is more often associated with intellectual and volitional characteristics.

The organization of a teenage group is largely determined by the position of its members. The teenager's ability to accept the goals of the group, its motives, values, its willingness to take initiative, to take responsibility characterizes its involvement in the life of a cohesive group of high level of development. This concept, in a certain way, differs in content with the concept of the status of the teenager's personality position in the system of interpersonal relationships, although these phenomena are closely related. Status reflects the position of the individual in the system of interpersonal relationships, and inclusiveness is considered as adequate or inadequate participation of the person in the life of the group, in the realization of its goals. Adequacy is determined by initiative, activity, efficiency, and inadequacy is determined by indifference, negativism, and irrelevant following by the group. When a group views a teenager's actions as worthy of imitation or approval, a state of certainty arises and an awareness that the group is legalizing and upholding or sanctioning its values. On the other hand, in the absence of adequate function in the group and the proper status position of the teenager, the importance of emotional bonds are decisive, and disturbances in this area cause tension, frustration, neuroses.

The phase of adaptation in adolescence is expressed in satisfying the need to be like a "significant other". This phase involves a number of tasks: to be like the reference peers, to be what the peers want to see him and to build relationships with adults as their peers reference them. A significant number of settings in adolescence are related to one or more social groups, as evidenced by the study of the influence of prestige, leadership of opinions, the rejection of membership groups by those who hold low status, the influence of external groups on the level of personality claims. In recognition of this fact, the term "reference group", which was first used by G. Hayman in 1942 to refer to a group of people with whom a subject compared himself to determine his status, was widely used. As a result, the comparison had a decisive influence on the self-esteem of one's status. In T. Newcom's (1953) works, the notion of referentiality is associated with a positive and negative attitude towards a group or groups 
and is enshrined in M. Sheriff's (1948) works as a point of reference for self-esteem and for the formation of a picture of the world and other researchers.

The phase of individualization, relatively prevalent at this age, as already noted, is characterized by the refinement and development of ideas about themselves, the active development of self-awareness, the expansion of contacts with peers. Personal relationships are of particular importance, and the further development of role-playing relationships contributes to the expansion of social ties.

Communication with significant people during this period is a source of both positive and negative experiences. Moreover, the negative can be compensated in the course of communication with others. However, if the teenager compensates for the loss in satisfactory communication with others, conflicts do not necessarily lead to social maladaptation. If he does not have such an opportunity, then compensation is obtained in another environment that may be asocial. In the phase of individualization, the need to "attract attention" is met by means developed in the system of relationships with peers, which can be manifested in the extraordinary behavior, in clothing, in sports achievements, emphasized courage, or in alcoholism, narcotics, early sexual debuts, excess audacity. This may be the basis for the subsequent criminalization of the teenager and his placement in a penitentiary

The integration of the teenager determines his / her readiness for the next period of development, which often goes beyond the formal group: school class, group in professional institute, college.

In general, theoretical analysis has necessitated the need for sociopsychological studies of features, patterns in the development of adolescent groups, their dynamics, phenomena of intragroup interaction and its socialperceptual features in special conditions of social deprivation.

\section{Introgroup structure and social perception in penitentiary institutions for minors}

Many theoretical and experimental works in the social, legal, penitentiary psychology of the post-Soviet period of the last decades of the late twentieth and early twentieth centuries were devoted to the study of the processes of group formation in special conditions, including in the 
conditions of social deprivation... [M. Bashkatov ${ }^{14,15}$, O. Betza ${ }^{16}$, T. Belavina ${ }^{17}$, M. Kondratyev ${ }^{18}$, V. Krivusha, V. Sinev ${ }^{19}$, etc.).

As already noted, the process of forming the necessary personal qualities is largely determined by the features of interpersonal relationships in each specific community. Issues related to the dynamics of personality and group development in penitentiary systems can also be attributed to the problem of group formation, intragroup structure, dynamic processes in the group and between groups in conditions of forced relative isolation of the group. There are in view of the group of juveniles sentenced to imprisonment, the peculiarities of the conditions of development of their personality, as well as the intragroup structure in the institutions of the juvenile law enforcement system.

The problem under study aims to identify the socio-psychological aspects of the formation and dynamics of intergroup and intragroup relationships of convicted adolescents, to determine what the impact of specific real social groups on these processes in conditions of forced isolation from society in a broad understanding of its significance.

One of the central problems of social psychology is traditionally considered to be the problem of group differentiation as an intra-group structure. Most of the authors of the study of group structuring reduce the concept of intragroup structure to consider it from the standpoint of "formality" and "informality". That is, as the relationship between the functional structure of the group and the structure of interpersonal relationships allows us to analyze group structuring from the standpoint of the "functional-emotional" approach ${ }^{20}$.

The idea of a small group as a specific element of the general social system implies the need to distinguish between external and internal

\footnotetext{
14 Башкатов И.П., Фицула М.Н. Основы исправления и перевоспитания несовершеннолетних осужденных в воспитательно-трудовых колониях. М.:ОВТК ГУИТУ - 1984. 324 с.

15 Башкатов И.П. Социально-психологические особенности развития криминогенных групп подростков // Психология и профилактика асоциального поведения несовершеннолетних. Тюмень: ТГУ, 1985. - C. $15-26$.

${ }^{16}$ Беца О. Соціальна адаптація осіб, звільнених із місць позбавлення волі // Соціальна політика і соціальна робота, 2002. - № 2. - С. 5-15.

17 Белавіна Т.І. Міжособистісні відносини в умовах соціальної депривації // Соціально психологічний вимір демократичних перетворень в Україні / За ред. Максименка С.Д., Циби В.Т., Шайгородського ЮЖ та ін. - К.: Український центр політичного менеджменту, 2003. - С. 357-369.

${ }^{18}$ Кондратьев М.Ю. Социальная психология закрытых образовательных учреждений. - СПб.: Питер, $2005-304 \mathrm{c}$

${ }_{19}$ Синьов В.М., Кривуша В.І. Пенітенціарна педагогіка: в запитаннях і відповідях: [Навчальний посібник] / В.М. Синьов, В.І. Кривуша. - К: ПМ Леся, 2002. - 123 с.

${ }^{20}$ Андреева Г.М. Социальная психология. М.: Аспект-Пресс. - 2000. С. 186-190.
} 
structure: the first is understood as a complex of socially defined causes of its formation, and the second is denoted by the problem of intragroup structuring. a set of functions corresponds to such a structure, which is a characteristic of the role ${ }^{21}$.

In M. Kondratiev's studies, the model of group differentiation is described in terms of "monostructure" and "polystructure" $"$. The monostructure characterizes in all spheres of group activity the situation of invariance of status hierarchy, which implies the fixation of low or high status always behind the same members of the group. These characteristics of the group in the conditions of the penitentiary institution have been obtained in numerous studies, including in the author's own studies ${ }^{23}$. Polystructure implies the presence of a large number of differing rank structures, each reflecting a status hierarchy in each individual sphere of group activity. Each of these types of structuring has both advantages and "disorganizing tendencies", different in character. The monostructure of interpersonal relationships in group activities, on the one hand, allows to quickly and effectively solve the tasks set, on the other - creates a rigid separation of statuses, leading them to polarization. And for the solution of various problems, for the optimization of interpersonal relations, polystructuring, which, at the same time, is able to cause intragroup division $^{24}$ will become more favorable.

In the context of this task, it is necessary to emphasize the importance of self-esteem in personal development. In the scientific literature, it is considered from various positions: as a component of self-awareness, as a determinant of behavior, etc. First of all, we note that self-esteem is the area of interest of various psychological disciplines: age, pedagogical, differential psychology, pathopsychology. Its characteristics are defined, research methods are developed, experience of theoretical and experimental study of self-esteem is accumulated.

In a number of studies, the dependence of the formation of an objective basis of the evaluative attitude of the individual towards himself

\footnotetext{
${ }^{21}$ Андреева Г.М. Социальная психология. М.: Аспект-Пресс. - 2000. С. 274-288.

${ }^{22}$ Кондратьев М.Ю. Социальная психология закрытых образовательных учреждений. - СПб.: Питер, $2005-304$ c.

23 Бєлавіна Т.І. Міжособистісні відносини в умовах соціальної депривації // Соціально психологічний вимір демократичних перетворень в Україні / За ред. Максименка С.Д., Циби В.Т., Шайгородського ЮЖ та ін... - К.: Український центр політичного менеджменту, 2003. - С. 357-369.

${ }^{24}$ Кондратьев М.Ю. Социальная психология закрытых образовательных учреждений. - СПб.: Питер, 2005 - 304 c.
} 
in the process of conscious development of the rules of relations in the real contact group is traced, the social determination of self-esteem is emphasized. As a structural component of the mental structure of personality, self-esteem determines the degree of its orientation in interpersonal communication. Self-esteem influences the effectiveness of the activity and the further development of the individual as a social quality of the individual. Its characteristics: resilience, adequacy, level of adaptability, and so on, are fundamental in the choice of behavior line, communication partner, as well as in relationships with others. It can be concluded that the interaction of the individual and the group gives birth to an infinite number of value systems that develop among members of a complex community, in which one can find support for almost any human manifestation.

Already in the first studies of self-esteem sounded socio-psychological terms. Thus, K. Levin ${ }^{25}$, L. Festinger ${ }^{26}$, and others identified, along with situational and personality, socio-psychological factors, such as group norms, standards, as determinants. Therefore, not only the individual but also the [...] group is the subject of many studies of self-esteem.

The formation of personality characteristics is inextricably linked to the success or failure of integration of the individual in the reference group and the level of development of that group, on which the conditions for satisfying the need for personalization depend. However, in groups with an antisocial focus (such as criminally oriented ones), the motive for avoiding failure due to the group's severe sanctions in case of failure is great. Thus, the need for social adjustment to the group is obvious, but the group can also be evaluated for the adequacy of one or another of its members. All our judgments, judgments, tastes, depend on the views of those we consider experts. If a community or group tries to equalize some of its members with others or leave them in isolation, it may be perceived as inadequate to the individual's needs and become a source of frustration for the individual's social needs.

If the norms of the membership group cease to conform or work for self-esteem, or the group impedes its preservation, the individual will seek to leave that group either physically or psychologically, that is, to select an

\footnotetext{
25 Левин К. Теория поля в социальных науках / [Пер. Е. Сурпина]. - СПб.: Речь, 2000. - 368 с.

${ }^{26}$ Festinger, L. Wish, expectation and group standards as factors influencing level of aspiration // Journal of Abnormal and Social Psychology, 1942, 37 (2), 184-200.
} 
external group as a standard. In this sense, the group is an active creator of standards and norms.

Changing the social status of a group in a relatively broad social environment can be a determinant of the dynamics of self-esteem in the group. Attempts to trace the dependence of self-esteem on belonging to a particular social group were made mostly in foreign psychology, by H. Heckhausen (1986), K. Levin ${ }^{27}$ and L. Festinger ${ }^{28}$. Despite the considerable accumulated theoretical material, the data on the impact of the broader society on self-esteem are scanty, they are scattered, and the problem requires further elaboration.

The cultural and social context, traditions, stereotypes of behavior, corresponding to, including, gender role, determine the direction of sexual socialization. The adult community that directly surrounds the child from birth, controls role behavior in terms of their acceptability. The system of self-esteem and preferences, the consciousness of one's gender, is formed under the influence of the attitude of others. During puberty, under the influence of hormonal processes and the influence of others, sexual identity is supplemented by certain sexual and erotic orientations and interests. Therefore, the gender aspect of this process deserves separate study beyond this private study.

In our study, we need to make some observations about the specifics of the sample, which represents the respondents: on the one hand, adolescents brought up in orphanages, and on the other, inmates of closed-type crime departments. These educational institutions have relatively similar characteristics: adequate socialization of students, social deprivation, as a partial limitation of opportunities in establishing new social ties and independence of group choice, etc. But their group isolation is different. Boarding students find themselves detached from the social environment by force, due to circumstances, without infringing on their rights and reducing their social status. Adolescents in a penitentiary institution are in isolation, to which the society consciously exposes them.

It is customary to single out relatively specific distinctive psychological traits of the students in the penitentiary systems: emotional instability, initial dependence on society, high stereotyping of public

\footnotetext{
27 Левин К. Теория поля в социальных науках / [Пер. Е. Сурпина]. - СПб.: Речь, 2000. - 368 с.

${ }^{28}$ Festinger L. Wish, expectation and group standards as factors influencing level of aspiration // Journal of Abnormal and Social Psychology, 1942, 37 (2), 184-200.
} 
opinion regarding their social position and stigmatization. These and some other features have a significant effect on behavior, especially on reactions to frustration and so on.

Research conducted by the author in similar groups earlier revealed some common features in the socio-psychological manifestations of both adolescents - boarding students and graduates of the departments of the department for the execution of crimes for committing crimes. To exclude indicators related to age-specific adolescent characteristics, high school students of the general school acted as a control group.

The findings revealed that the situation of the juvenile prisoners in closed institutions is significantly different from the situation and behavior of adolescents. raised in a boarding school. The total deprivation of the penitentiary system significantly affects the self-attitude of its students clearly in a more unfavorable way.

At the same time, purposeful observation, discussions with orphanage staff and other research participants made it possible to conclude that there is a strong stigma on the part of the wider society, both those adolescents who are in detention and those who are brought up outside the family, but less deprived of spatial movement, choice of group, establishment of new social ties, freedom to choose forms of leisure.

It should be defined as a factor of negative influence on the process of personal formation of teenagers in a small group and in the conditions of society. The possibility of personal deformation becomes apparent, and its extent and features are likely to be determined not only by the social situation of development (objectively), but also by the attitude of the subjects themselves, by how they perceive the given situation (subjectively).

Particularly noteworthy is the fact that until now, there has been virtually no research aimed at examining the features of awareness of perception of the broader society. Such a task made it possible to make some assumptions, in that part, where the specificity of interpersonal relationships and group formation is supposed to depend on the evaluative attitude of the society as a whole and on the awareness of the contingent sampling of the social status of the social structure and the group to which they belong. 


\section{3. "I-confrontation" and "I-identification" in conditions of forced comparison of yourself with peers}

The study participants are closely related to the degree and nature of the orientation of the "Self-confrontation" and "Self-identification" processes in the context of forced comparison of peers who are brought up in a fundamentally different social situation: in the orphanage or in institutionally closed educational and educational institutions. institutions of the enforcement system.

The paper attempts to summarize some of the results concerning precisely the socio-psychological issues of forming a self-esteem personality, the social-perceptual aspects of this process, on the basis that the condition of understanding the personality is a psychological analysis of the communities in which it is included. That is, it is about the dependence of self-esteem on the characteristics of small groups and interpersonal interactions, in particular, the influence of the reference group. Self-esteem depends on how the group standards are formed and changed, the parameters of self-esteem, and how each member of the group takes part in their formation and change. Often this problem is solved by designating an alternative: either the individual passively accepts the norms and expectations of the group, that is, demonstrates conformal behavior, or maintains his "level of self." In such a case, his confrontation with the group is inevitable.

The revealed patterns partially reveal the peculiarities of the awareness of teenagers serving their sentence in penitentiary conditions, the specifics of the attitude of orphanage students to them. These regularities are revealed as a result of the comparison of really revealed sociometric choices, as well as the results of the use of the method of false self-esteem. Of course, this data is not enough for a deep analysis of the nature of expectations about the evaluative attitude of the broader social environment.

Research conducted previously on the psychological features of depressed adolescents (I.P. Bashkatov ${ }^{29,30,31}$, G.G. Bochkareva, 1968,

\footnotetext{
29 Башкатов И.П., Фицула М.Н. Основы исправления и перевоспитания несовершеннолетних осужденных в воспитательно-трудовых колониях. М.:ОВТК ГУИТУ - 1984. 324 с.

30 Башкатов И.П. Социально-психологические особенности развития криминогенных групп подростков // Психология и профилактика асоциального поведения несовершеннолетних. Тюмень: ТГУ, 1985. - C. $15-26$.

31 Башкатов И.П. Психология групп несовершеннолетних правонарушителей: Социальнопсихологические особенности (Монография). М.: Прометей, 1993. - 312 с.
} 
E.I. Dranishcheva, 1972, M.U. Kondratiev ${ }^{32}$, etc.) have shown that the regime closure of an institution in which a young man is a teenager can not but generate the specifications of personal development. The narrowing of the channels of communication with the broad society creates a rigid formation of an intra-group hierarchy. The secrecy of the group puts it in a situation of opposition to society, depending on belonging to a particular social environment, although the group does not set similar tasks. Depressed teenagers confront the social environment, but do not want to agree with the view that they are qualitatively "worse" children, from another social reality. They are characterized by a willingness to accept and respond to the favorable attitude of the social environment from both peers and adults.

Thus, it can be concluded that prolonged group isolation in certain circumstances is characterized by the loss of certain mental bonds, isolation of the usual, needy, complication of the psychological content of the activity.

The study examined the questions about: 1) how the self-esteem of the boarding school and penitentiary institution differs in the situation of forced assessment confrontation; 2) what is the awareness of the evaluative attitude towards themselves from the other social environment among the graduates of institutions of different degree of regime, 3) what is the nature of the orientation of the processes of "I-confrontation" and "I-identification".

The study used the results of a survey of adolescents sentenced to imprisonment of prisoners (50 male adolescents aged 14 to 17 years) and boarding schools for orphans and children deprived of parental care (49 male adolescents over 14 years of age). To obtain a more complete picture of the processes of self-confrontation and self-identification, the technique of comparing oneself to a quasigroup was used.

The tasks identified in the study aim to give special attention to the structure of ranks in such groups under conditions of forced isolation.

In order to obtain the empirical material needed to illuminate the answers to the questions we were interested in, a sociometric technique was used according to functional criteria, as well as a modified technique of "false self-assessment".

12. Кондратьев М. Ю. Социальная психология закрытых образовательных учреждений. СПб.: Питер, 2005 - 304 с. 
The first technique revealed the status positions in both contingent samples and the intragroup structure of the two groups studied. A group of adolescents in a penitentiary institution built relationships by the type of monostructure, that is, they showed in all spheres of group activity a situation of invariance of the status hierarchy, which implies the attachment of low or high status always to the same members of the group. The orphanage students demonstrated the presence of a large number of different rank structures in each area of group activity, indicating group formation by type of polystructure.

The modified version of the methodology of "false self-assessment showed the orientation of the processes of "I-identification" of "I-confrontation" in the situation of forced comparison of myself with peers. The subjects were offered a questionnaire for self-assessment, where 12 characteristics were determined, half of which were conditionally classified as socially approved, and half had relatively negative content: self-esteem, self-confidence, kindness, justice, sociability, modesty, modesty, aggressiveness, light-heartedness, aggressiveness, vigilance, passivity.

Recall that the results were obtained by presenting to each member of the groups of boarding school students and the penitentiary institution their own self-assessment under the guise of a self-assessment form filled out by the graduates of another type of institution, in terms of their institutional closure. Carrying out a similar procedure made it possible to see that the students of the boarding school, initially, are in a more favorable position and their positions are socially supported. Therefore, they act from the standpoint of society, as individuals with a sociallyapproved form of behavior unlike the graduates of the penitentiary department.

Seeing themselves in a more favorable light about the broader social environment compared to their peers from the educational institutions of the penitentiary system, the students of boarding school raise their own self-esteem in the situation of comparing themselves with them, clearly confronting with indicators of the quasi-group and convicting themselves self-esteem indicators.

A special place is occupied by low-status boarding school students, who tend to identify themselves with the students of the educational colony. 
The positions of "average" in both samples were statistically indistinguishable.

Indicators for adolescents in the penitentiary system were different. Despite their increased willingness to receive a favorable evaluation from the side, adolescents in a penitentiary do not have a particular sympathy for those deprived of parental care and prefer to identify with the same as themselves. This, underscores the objectively existing fact of the disadvantaged position of the graduates of the closed institutions among the representatives of the society outside the penitentiary institution.

The prejudiced attitude of "family" peers from penitentiary institutions, educators and society in general is expressed in the absence of a favorable attitude towards orphans and the presence of a negative attitude given by the stereotypical view of this contingent of subjects in ordinary consciousness.

In general, our assumption about the status determination of the dynamics of self-esteem has been confirmed in the process of its verification by experiment.

The result of the procedure is a "new" self-assessment, which is determined by the features of the stimulus material, which before the second series was presented to the subject. We mean the information that characterizes the "other" who is credited with the authorship of the completed form under the experimental conditions. The magnitude and direction of the change in self-esteem are conditioned by what the test taker considers to be the received form with his or her own self-esteem portrait.

The use of this procedure in other studies and for solving other problems has revealed some patterns of self-esteem dynamics or its stability

a) stability of self-esteem is conditioned by presentation of the subject's own self-esteem under the guise of self-esteem of a significant or authoritative person for him;

b) "shift" in the assessment of one's personal characteristics is most noticeable if the subject is informed that the form presented to him is filled with a negative reference for him, that is, his opinion for the subject is very important, but he treats this person with deep dislike;

c) is submitted under the guise of self-assessment of a member of the group, which is clearly different from the subject in terms of status, physical strength, etc. 
Consequently, the technique of false self-assessment allows not only to determine the degree of expressive influence of another person on the person of interest, but also gives the possibility of the most effective way of educational influence, selection and design of corrective programs. Such specificity of the result requires a particularly careful interpretation of the empirical data.

Given that at the threshold of adolescence there is a crisis of self-esteem, which is accompanied by an update of the need for self-affirmation, then the specific conditions of communication that develop in institutionally closed educational institutions, the lack of emotional well-being often lead to the formation of conflict situations. And the inability of self-affirmation of adolescents brought up in closed institutions in various spheres of activity, as a rule, leads to the emergence of ugly forms of individualization, such as malicious negativism, cynicism, cluelessness, abandonment of various activities and others.

\section{CONCLUSIONS}

To sum up, it should be concluded that the broad society in Ukraine has long been formed under the influence of unlimited power of the state, state institutions of subordination and violence, and in the sphere of education and upbringing under the influence of the priority of logocracy and punishment. The society has long favored predetermination and total control, and in the current conditions of social transformation of society there is a need to develop such social institutions that could reconcile both the interests of the state and the private values and interests of the people, it is necessary to promote the development of mechanisms of autonomy of private life.

Penitentiary systems partly act as a diminished model of a sociable congruence and possess all the hallmarks of socializing influence, especially when it concerns adolescents. The inability to self-affirm adolescents brought up in closed institutions or its restriction, as a rule, leads to the emergence of ugly forms of individualization, such as malicious negativism, cynicism, expletive behavior, rejection of various activities and other destructive forms of behavior.

The specific conditions of communication that develop in closed educational institutions of varying degrees of incarceration (boarding school, educational colony), lack of emotional well-being often lead to the formation of conflicting unstable self-esteem and the emergence of situational and personal anxiety. 
Adolescents who are in a penitentiary institution do not have much sympathy for those deprived of parental custody and prefer to identify with the same as themselves. This, underscores the objectively existing fact of the unfavorable position of the graduates of closed institutions among the representatives of the society outside the penitentiary institution.

A positive or negative "shift" in the assessment of one's personal characteristics depends on the recognition of a positive or negative attitude in the society towards a group, a member of the group to which he or she is in a confrontation.

It was found that there is a definite relationship between the degree of regime, closedness, the priority of the prescribed behavior of the educational institution and the characteristics of grouping, interpersonal perception in really functioning groups of adolescents. These processes generally follow the same pattern as in a juvenile detention facility, but the specific form of manifestation of group formation and group structure has their specificity.

\section{SUMMARY}

The publication reveals some aspects of the life of a person and a group of minors in prison systems, which, to a certain extent, can act as a reduced model of a sociable congruence. The problem of group formation in conditions of forced relative isolation of a group in relation to minors, from the standpoint of social psychology, is considered.

The socio-psychological features of intergroup and intragroup interaction in adolescent groups and its social-perceptual aspect have been determined; peculiarities of intragroup structure of real groups under conditions of penitentiary institution are studied.

There is a description of the connection between the degree of regime, closedness, priority of the prescribed behavior of the educational institution and features of grouping, interpersonal perception in really functioning groups of adolescents.

It is established that these processes as a whole proceed according to the same scheme as in the conditions of an adult penitentiary institution, but the specific form of manifestation of group formation and group structure has their specificity in them.

It can be described as a problem related to group formation in conditions of forced relative localization and isolation of the group in relation to a certain contingent, a specific type of joint activity, to a certain 
age, gender, from the standpoint of not only general, age and pedagogical, but also social psychology.

On this basis, it is necessary to determine the socio-psychological aspects of intergroup and intgroup interaction in adolescent groups, its social-perceptual aspect; to study peculiarities of intragroup structure of real groups in conditions of penitentiary institution.

The publication reveals some aspects of the life of a person and a group of minors in prison systems, which, to a certain extent, can act as a reduced model of a sociable congruence. The problem of group formation in conditions of forced relative isolation of a group in relation to minors, from the standpoint of social psychology, is considered.

The socio-psychological features of intergroup and intragroup interaction in adolescent groups and its social-perceptual aspect have been determined; peculiarities of intragroup structure of real groups under conditions of penitentiary institution are studied.

There is a description of the connection between the degree of regime, closedness, priority of the prescribed behavior of the educational institution and features of grouping, interpersonal perception in really functioning groups of adolescents.

It is established that these processes as a whole proceed according to the same scheme as in the conditions of an adult penitentiary institution, but the specific form of manifestation of group formation and group structure has their specificity in them

\section{REFERENCES}

1. Андреева Г.М. Социальная психология. М.: Аспект-Пресс. 2000. С. 186-190, 274-288.

2. Асмолов А.Г. Психология личности: культурно-историческое понимание развитие человека (3-е изд. Испр и доп.). - М., Академия, Смысл, 2007. - 528 с.

3. Багрецов С.А. и др. Диагностика социально - психологических характеристик малих груп. - СПб.: Питер,1999. - 638 с.

4. Башкатов И.П., Фицула М.Н. Основы исправления и перевоспитания несовершеннолетних осужденных в воспитательнотрудовых колониях. М.:ОВТК ГУИТУ - 1984. 324 с.

5. Башкатов И.П. Социально-психологические особенности развития криминогенных групп подростков // Психология и 
профилактика асоциального поведения несовершеннолетних. Тюмень: ТГУ, 1985. - С. 15-26.

6. Башкатов И.П. Психология групп несовершеннолетних правонарушителей: Социально-психологические особенности (Монография). М.: Прометей, 1993. - 312 с.

7. Бєлавіна T.I. Міжособистісні відносини в умовах соціальної депривації // Соціально - психологічний вимір демократичних перетворень в Україні / За ред. Максименка С.Д., Циби В.Т., Шайгородського Ю.Ж. та ін. - К.: Український центр політичного менеджменту, 2003. - С. 357-369.

8. Бехтерев, В.М. Основные задачи рефлексологии физического труда [Текст] / В.М. Бехтерев // Вопросы изучения и воспитания личности. - 1919. - № 1. - С. 51.

9. Беца О. Соціальна адаптація осіб, звільнених із місць позбавлення волі // Соціальна політика і соціальна робота, 2002. № 2. - С. 5-15.

10. Зиммель Г. Социальная дифференциация: Социологические и психологические исследования / Г. Зиммель // Избран. в 2 т: Т. 2 : Созерцание жизни. - М: Юрист. - 1996. - 164 с.

11. Кули Ч. Человеческая природа и социальный порядок : [Науч. изд.] : пер. с англ. / Ч. Кули М. : Идея-Пресс : Дом интеллектуальной книги, 2000. - 309 с.

12. Кондратьев М.Ю. Социальная психология закрытых образовательных учреждений. - СПб.: Питер, 2005 - 304 с.

13. Левин К. Теория поля в социальных науках / [Пер. Е. Сурпина]. - СПб.: Речь, 2000. - 368 с.

14. Морено Я.Л. Социометрия: Экспериментальный метод и наука об обществе / Пер. с англ. А. Боковикова. - М. :Академический проект, 2001. - $320 \mathrm{c}$.

15. Олейник А.Н. Тюремна субкультура в Росії: від повсякденного життя до державної влади. - М.:ИНФРА - М., 2001, $\mathrm{X} 1 \mathrm{Y}, 418 \mathrm{c}$.

16. Олпорт Г. Становление личности: Избранные труды / [Пер. с англ. Л.В. Трубицыной и Д.А. Леонтьева]; под общ. ред. Д.А. Леонтьева. М.: Смысл, 2002. - 462 с.

17. Петровский А.В. Психология развивающейся личности: монография. М.: Педагогика, 1987. - 240 с. 
18. Пирожков В.Ф. Криминальная психология. - М.: «Ось-89», 2007. - 704 c.

19. Пономарев, С.Б. Синдром тюремной социальной депривации в молодом возрасте / С.Б. Пономарев и др. - Екатеринбург, 2008. -27 с.

20. Психологія групової ідентичності: закономірності становлення: [монографія] / [П.П. Горностай, О.А. Ліщинська, Л.Г. Чорна та ін.] ; за наук. ред. П.П. Горностая. - К. : Міленіум, 2014. - 252 с.

21. Синьов В.М., Кривуша В.I. Пенітенціарна педагогіка: в запитаннях і відповідях: [Навчальний посібник] / В.М. Синьов, B.I. Кривуша,. - К: ПМ Леся, 2002. - 123 с.

22. Соціальна робота 3 неповнолітніми, які перебувають у місцях позбавлення волі.// За ред. Синьова В.М. - К., 2003. - 222 с.

23. Тард Г. Социальные законы Пер. с фр. Изд. 2-е. - М.: Книжный дом «ЛИБРОКОМ», 2009. - 64 с.

24. Хрящова, Н.Ю. Психические состояния при изоляции / Н.Ю. Хрящова. - СПб.: Питер, 2000. - 413 с.

25. Шевченко Л.А. Личность преступника в гендерном измерении // Личность, семья и общество: вопросы педагогики и психологии: сб. ст. по матер. LXXI междунар. науч.-практ. конф. № 12 (69). - Новосибирск: СибАК, 2016. - С. 33-41.

26. Moede W. Experimentelle Massenpsychologie. Beitrage zur Experimentalpsychologie der Gruppe. - Leipzig: Hirzel, 1920. - 239 p.

27. Festinger, L. Wish, expectation and group standards as factors influencing level of aspiration // Journal of Abnormal and Social Psychology, 1942, 37 (2), 184-200.

\section{Information about the author: Bielavina T. I. $\mathrm{PhD}$ in Psychology,} Associate Professor at the Department of Psychology and Pedagogy of the Scientific and Humanitarian Institute of the V. I. Vernadsky Taurida National University 33, Ivana Kydri str., Kyiv, 01042, Ukraine 